\title{
Power quality comparison of single-phase and three-phase inverter topologies for renewable energy systems
}

\author{
Mert Saçl1 $^{\mathrm{a}^{*}}$, Onur Ayan ${ }^{\mathrm{a}}$, Murat Silsüpür ${ }^{\mathrm{a}}$, and Belgin Emre Türkay ${ }^{\mathrm{a}}$ \\ ${ }^{a}$ Istanbul Technical University, Istanbul, Turkey
}

\begin{abstract}
In recent years, electricity demand has been increasing, whereas conventional or petroleum-derived energy resources which are used for generating electrical power have been decreasing day by day. On the other hand, environmental problems due to petroleum-derived energy resources are another vital issue in the world. Renewable energy resources play a crucial role in less global warming, improving public health and inexhaustible energy. Inverters are one of the main components of renewable resources such as solar cells, wind turbine, fuel cells etc. Power quality is one of the major problems for all power systems. Power quality is getting more complicated by integrating renewable energy systems. For this reason, power quality effects of inverters must be investigated. In this study, different single and three-phase inverter topologies were designed and analyzed. In terms of single-phase four different topologies, in terms of three-phase, three different topologies were modeled. All topologies were investigated for current waveform under varying load conditions and compared in terms of DC injection, total harmonic distortion (THD) and individual harmonics with the help of PSIM and MATLAB Simulink.
\end{abstract}

Keywords: Inverters, PWM, SPWM, Power quality, THD, Harmonics.

\section{Introduction}

Energy is a vital thing for the continuation of our daily life. Energy can be defined as the capacity of a physical system to do work. There are lots of energy forms such as mechanical energy, light energy from the sun, heat energy, chemical energy, nuclear energy, and electrical energy. Throughout history, with the development of humanity, energy has been generated in various forms, and the use of energy has spread over a wide area [1].

Energy can be classified into 2 main categories according to areas of utilization such as renewable and non-renewable energy resources. Renewable energy is an energy resource that is replaced rapidly by a natural process, or it is an energy source that is naturally replenished. Wind turbines, fuel cells, solar cells, nuclear energy, and hydroelectric energy are examples of renewable energy resources. Non-renewable energy sources or natural resources are those sources that drain fossil reserves deposited over centuries. This results in depletion of these energy reserves. The four primary nonrenewable energy sources are natural gas, coal, uranium (nuclear energy), and crude oil. Despite decreasing of limited conventional resources, $80 \%$ of electrical energy is generated from conventional energy resources [2]. Due to burning fossil fuels, 21.3 billion tons of $\mathrm{CO} 2$ were released, but researches show that about half of the natural resources to be absorbed, that is, a net release of 10.65 billion tons of $\mathrm{CO} 2$ [3]. For these reasons all around the world, the number of renewable energy researches grows up also RES is increasing day by day.

Due to these reasons, increasing the share of RES in electricity generation is inevitable. RES has many advantages for the environment, but there are some difficulties. Power quality is getting more complicated with the inevitable integration of RES to the interconnected systems. Disturbances in the

\footnotetext{
* Manuscript received July 3, 2018; revised January 24, 2019.

Corresponding author Mert SAÇLI Tel.:+90 5383413801 ; E-mail address: saclim@itu.edu.tr

doi: 10.12720 /sgce.8.2.174-183
} 
quality of electrical energy may impair the end user equipment may cause the devices to malfunction. Due to low-quality energy, significant losses can occur for industrial sectors where very precision processes such as semiconductor industries [4]. For these reasons, energy quality of power systems should be investigated profoundly. This project firstly aims to design different single and three-phase inverter topologies for using renewable energy systems under different load condition. Secondly, it focuses on analyzing and comparing regarding DC injection, total harmonic distortion and individual harmonics with the help of PSIM and MATLAB Simulink.

\section{Inverter}

Inverters are indispensable components for most industrial applications. They are widely used in various motor types and power systems. The most commonly used inverter topologies are basic inverter topologies and multi-level inverter topologies. An inverter can be defined as a tool which converts a DC input voltage to the desired amplitude and frequency AC output voltage. Another definition of an inverter according to IEEE dictionary is an electronic device or circuit that changes direct current (DC) to alternating current (AC) [5]. Voltage, current, and frequency can be adjusted to an appropriate level. The frequency of output voltage can be constant or variable.

Inverters can be classified according to different properties such as output level as 2-level and 3-level; in terms of output waveform: square waveform, modified square waveform, True sine waveform; in terms of controlling type: voltage source inverter and current source inverter; in terms of phase condition: single and three-phase etc. [6].

There are many semiconductors used in inverters circuit such as IGBT, MOSFET, etc. In addition to this, there are many controlling techniques for switching these semiconductors such as pulse width modulation (PWM), sinusoidal pulse width modulation (SPWM), selective harmonic elimination (SHEPWM), space vector modulation (SVM), and others [7].

Ideally, inverter output is expected to be sinusoidal but in practice, the waveforms at the inverter output are not sinusoidal, and they contain harmonics. Although some of these harmonics should be an acceptable level, in high power applications these harmonics should be reduced, and low decaying sinusoidal waveforms are required. The harmonics of the output voltage can be significantly reduced by switching techniques with high-speed semiconductor elements. [8]

Inverters are a source of harmonics originating from converting DC to AC for RES. Investigate of inverters is so essential for power quality.

\section{Methodology, Modeling, and Simulation}

Investigate power quality effects of inverters are significant. In this study, 7 circuit topologies were implemented and designed: half-Bridge, full-bridge with PWM generator in Simulink and full-bridge 2level SPWM and 3-level SPWM as single-phase; full-bridge 2-level controlled, uncontrolled and cascaded connected 3-level inverter as 3-phase. MOSFET and IGBT transistors are used in this study. All transistors are controlled with PWM. In this study, PWM is produced with two techniques: SPWM and natural sampling PWM. These PWM signals are used to control switches. Through an LC filter, the output of inverter generates a wave approximately equal to a sine wave and keeping the THD between limits according to IEEE standards 1547.2003. LC filter properties are important for eliminating harmonics based on inverter so cut-off frequency should be determined properly. In the first part, LC filter is used same for all topology due to comparing inverter effects on THD second part L, and C value was increased at proper value due to keeping the THD between IEEE standards 1547.2003. It is commonly used that basically cut-off frequency of LC filter is [9]:

$$
f_{0}=\frac{1}{2 \pi \sqrt[2]{L C}}
$$


$\mathrm{L}$ is inductance value and $\mathrm{C}$ is capacitance value. It is known that typically an LC filters capacitance value should be maximum and inductance value should be minimum according to cut-off frequency. In this paper, $\mathrm{L}$ and $\mathrm{C}$ values were determined according to the $1000 \mathrm{~Hz}$ cut-off frequency. For all circuit, $\mathrm{L}$ is determined $8 \mathrm{mH}$ and $\mathrm{C}$ is determined $3.16 \mu \mathrm{F}$. As mentioned above for all topologies THD limits should be between IEEE 1547.2003 standards. Due to this reasons, capacitor value is increased up to 100 $\mu \mathrm{F}$ for single-phase topologies. All L and $\mathrm{C}$ values are based on a real project's data which provided by one of this paper author Dr. Murat Silsüpür.

Input voltage is determined $350 \mathrm{~V}$ for full-bridge and $700 \mathrm{~V}$ for half-bridge for single-phase topologies; also for 3-phase topologies, the input voltage is determined $700 \mathrm{~V}$ for uncontrolled and controlled fullbridge topology and $450 \mathrm{~V}$ for cascaded $\mathrm{H}$-bridge each bridge.

Power of inverter is determined as $10 \mathrm{~kW}$, it means inverter power of single-phase topologies is $10 \mathrm{~kW}$, and three-phase topologies inverter power is $30 \mathrm{~kW}$. All topology analyzed under $25 \%, 50 \%, 75 \%$ and $100 \%$ resistive load condition, so all topologies analyzed at power $2.5 \mathrm{~kW}, 5 \mathrm{~kW}, 7.5 \mathrm{~kW}$, and $10 \mathrm{~kW}$ resistive load condition as a phase. It is important because aims of this study examine to the effects of inverters on power quality not to effects of non-linear loads. The output voltage is $220 \mathrm{~V}$ as a phase and output frequency is $50 \mathrm{~Hz}$ for all topology. All inverter topologies as mentioned above voltage source inverter, so voltage is kept constant at $220 \mathrm{~V}$ with changing modulation index. SPWM is generated with comparing between a sine wave and a carrier waveform. The modulation index is the amplitude of the sine wave divided by the amplitude of the carrier waveform. [10]:

$m=\frac{\text { Vsine }}{\text { Vcarrier }}$

Two different PWM generation techniques are used in this paper. SPWM and natural sampling-PWM which produced PWM generator in Simulink is used for pulses for semiconductors. SPWM is a carrierbased pulse width modulation technique. Two signals are compared with a comparator, and the obtained signal was used as gating pulses. When the sinusoidal wave has a magnitude higher than the triangular wave, the comparator output is high; otherwise, it is low. The natural sampling technique models the behavior of an analog implementation of a PWM generator (MATLAB). PWM with Natural sampling technique and SWPM and gating pulses is shown in Fig 1.

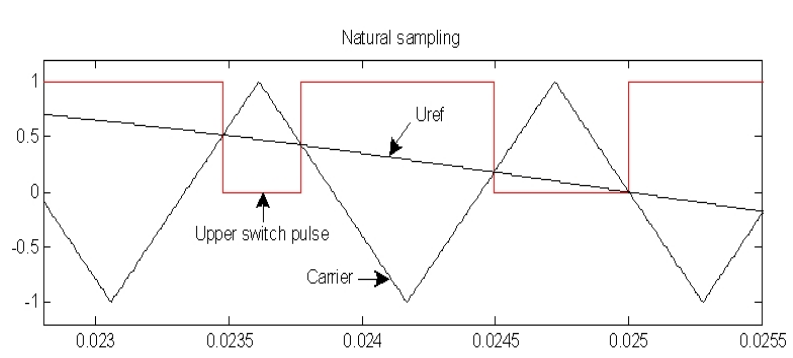

(a)

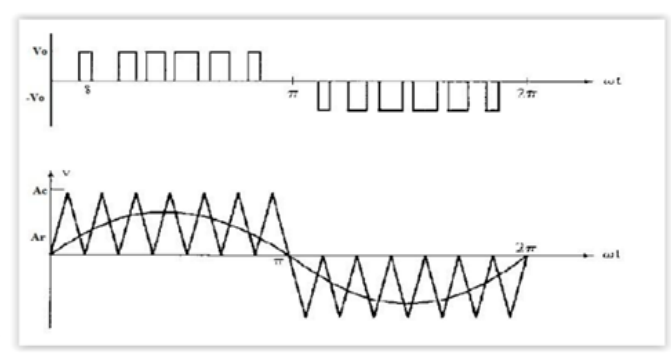

(b)

Fig 1. Natural sampling PWM(a) and sinusoidal $\operatorname{PWM}(\mathrm{b})$ respectively and gate pulses

THD, individual harmonics, and DC bias current were observed for power quality analysis. Fast Fourier Transform (FFT) block was used for THD and individual harmonics in MATLAB/SIMULINK and PSIM. THD tool is used in PSIM and THD block is used in Simulink for comparing and consistency of calculated value.

\subsection{Single-phase topologies}

Four different single-phase topologies were designed and analyzed: Half-Bridge, Full-Bridge with PWM generator in Simulink and Full-Bridge 2-level SPWM and 3-level SPWM in PSIM as a single phase. The half-Bridge inverter is modeled with the help of SIMULINK. There is a leg which contains two semiconductors in this topology. Natural sampling PWM was used for switching semiconductors, 
and reference signal was generated internally. Semiconductors are switched on/off respectively if semiconductors on mode at the same time, short-circuit occurs. When IGBT1 on, IGBT2 off, the output voltage equal to Vs/2; the other state IGBT1 off, IGBT2 on, the output voltage equal to $-\mathrm{Vs} / 2$. Vs is the input voltage. The output voltage was kept constant at $220 \mathrm{~V}$ with changing $\mathrm{U}_{\text {ref }}$. Single-Phase half-bridge inverter with natural-sampling PWM is shown in Fig.2a. Input voltage is determined two times of fullbridge single-phase topologies due to output voltage half of modulation index times input voltage whereas full-bridge topologies output voltage equals modulation index times the input voltage. The second topology is full-bridge topology. The full-bridge inverter was modeled as H-bridge with 4 IGBTs in Simulink. The simulation model of single-phase half-bridge inverter with natural-sampling PWM is shown Fig.2b. PWM was generated like in half-bridge topology. The freewheeling diodes permit current to flow even if all switches are open. The gate signal G1 and G3 are different signals, and G2 and G4 are opposite of G1 and G3 respectively. If same time closing in the same leg would cause short-circuit from DC supply to ground. This condition is known as shoot-through.

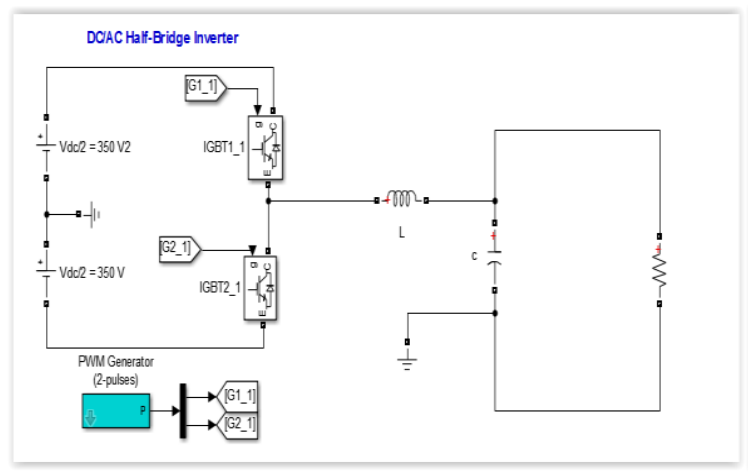

(a)

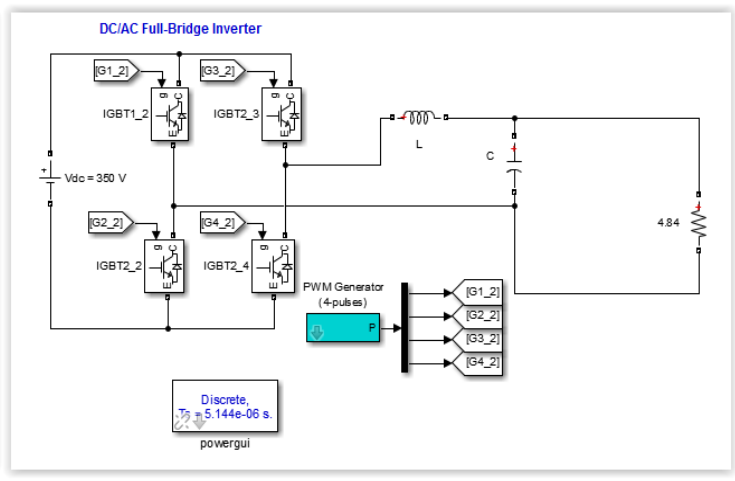

(b)

Fig .2. Single-phase half-bridge(a) and full-bridge(b) inverter with natural-sampling PWM

The third single-phase topology is full-bridge topology which controlled with SPWM. Single-phase 2level SPWM full-bridge inverter is shown in Fig.3a. Pulses are 2-level SPWM, so there is a carrier signal. Another single-phase topology is full-bridge topology with 3-level SPWM, and it is shown in Fig.3b. Circuit topology is same as other full-bridge topology, but control technique is 3-level SPWM. SPWM is generated with comparing sine wave and two different carrier waveforms. There is phase-opposition between carrier signals. These means there is phase-shifting between signal as $0^{\circ}$ and $180^{\circ}$ and $\mathrm{DC}$ offset between signals.

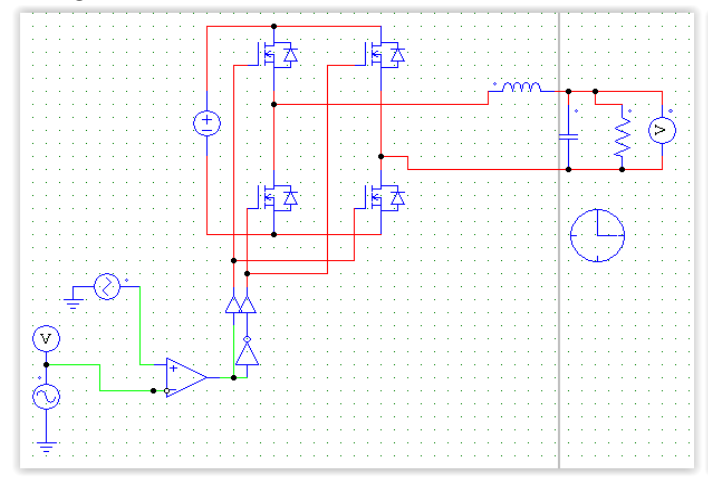

(a)

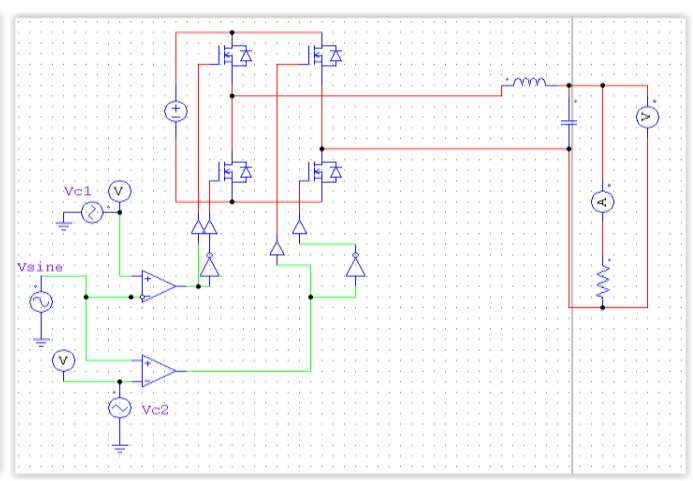

(b)

Fig 3. Single-phase half-bridge(a) and full-bridge(b) inverter with Natural-Sampling PWM 


\subsection{Three-Phase topologies}

The second part, 3 different 3-phase inverters are modeled: H-bridge 2-level SPWM with manually controller, H-bridge 2-level with a controller and, 3-level cascaded H-bridge inverter [11].

First 3-phase topology is a 3-phase full-bridge inverter, or it is known that 3-phase universal bridge inverter. The circuit was modeled and analyzed in PSIM, and it is shown in Fig.4. There are 3 legs and 6 MOSFETs in the circuit. 2-level SPWM was used for switching semiconductors, and there are 3 carrier waveforms which are phase-shifting $120 \mathrm{o}$ each other in between.

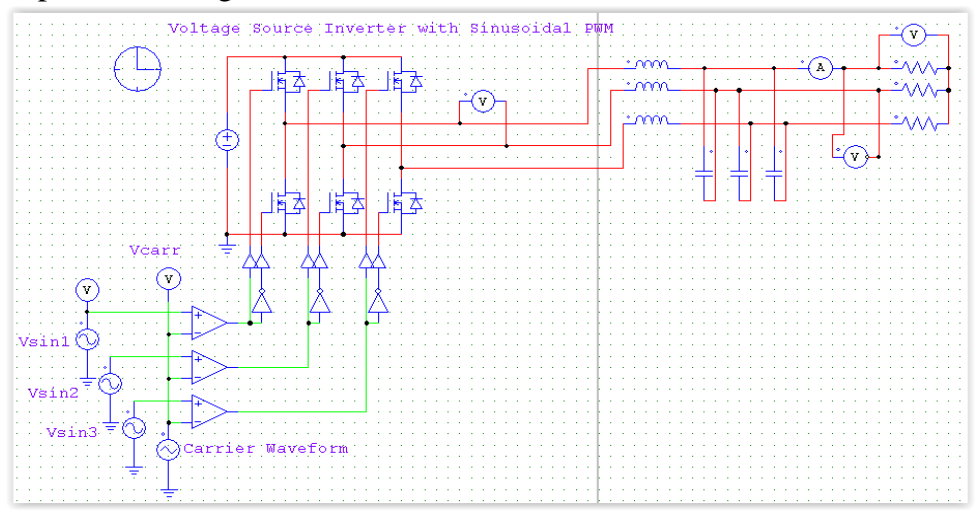

Fig 4. 3-Phase uncontrolled 2-level SPWM full-bridge inverter

The second topology is three-phase closed-loop universal bridge topology, and it is shown in Fig.5. All circuit parameters and control topology is as same as 2-level SPWM uncontrolled topology. This topology aims to observe controlling effects on power quality. Voltage is kept constant with an automatic controller according to variable load conditions. Automatic controller unit consists of 3 part: a phaselocked loop unit (PLL), abc to dq transform and PI controller. Voltage controller block in SIMULINK was used for automatic controller unit.

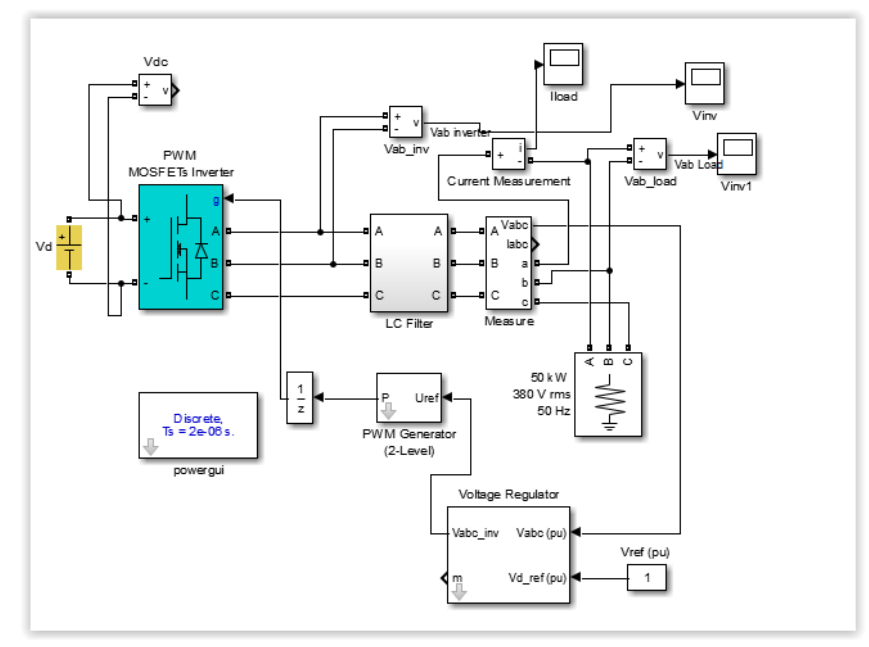

Fig 5. 3-Phase 2-level controlled SPWM full- bridge inverter

Another topology 3-phase 3-level cascade-connected inverter and it can be shown in Fig 6. There are 3 different cascaded connected single-phase universal bridge. 3-level SPWM is produced with 3 sine waves which are $120^{\circ}$ phase shifting and 6 different carrier waveforms [12]. There are phase disposition and shifting between carrier waves [13]. There is $180^{\circ}$ phase shifting between carrier signals. [14]. Sine wave amplitude was changed due to changing load condition. In this topology, 3 DC sources are required. Voltage sources can be the same or different. In this study, 3 DC sources are identical and $350 \mathrm{~V}$. 


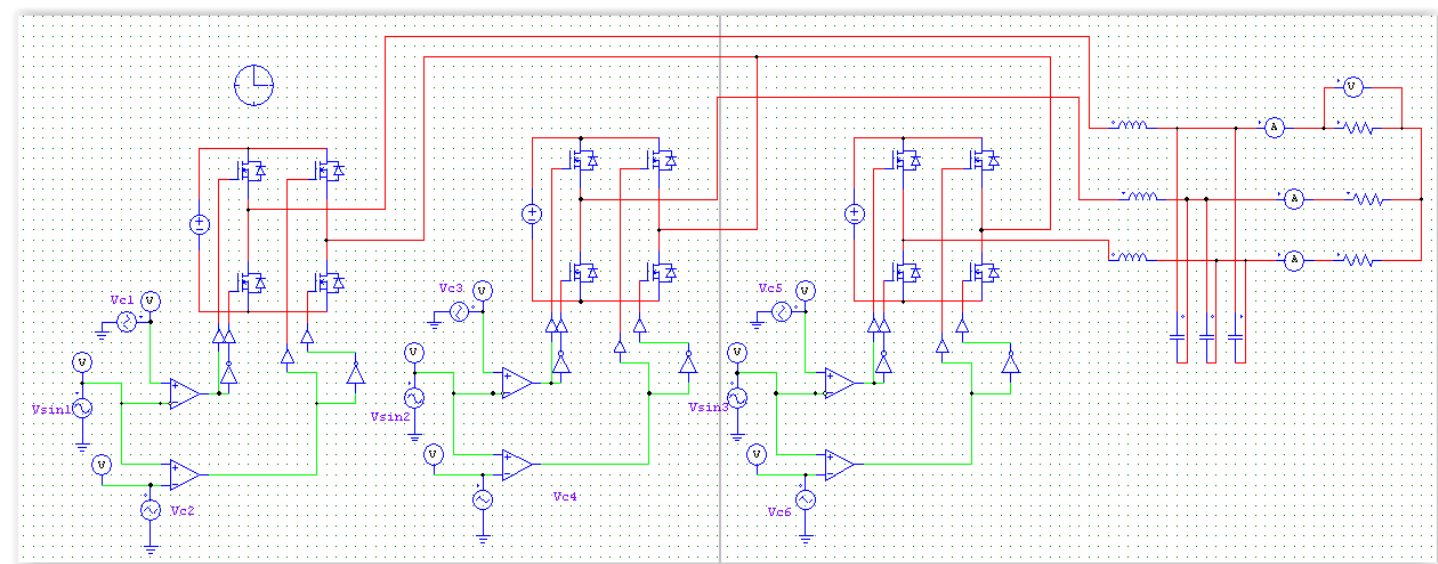

Fig 6. 3-Phase 3-level cascade SPWM full- bridge inverter

\section{Result and Comparison}

All designed circuit topologies were simulated under 25\%, 50\%, 75\% and $100 \%$ resistive load condition. Resistance was changed according to the desired load condition. LC filter properties are as same as for all topologies. FFT analysis of full load condition of single phase topologies with natural sampling PWM is shown in Fig.7, single phase topologies with SPWM is shown in Fig. 8, and threephase topologies are shown in Fig. 9.

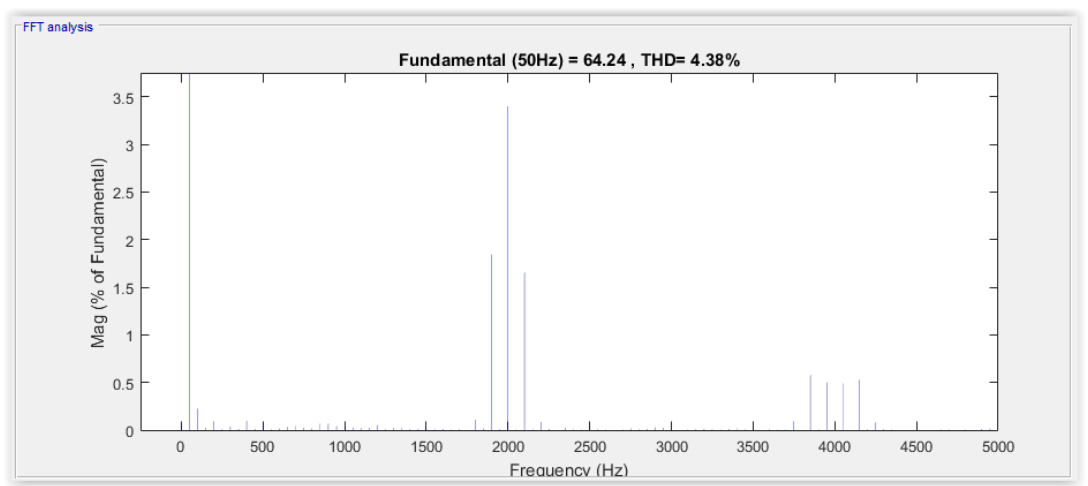

(a)

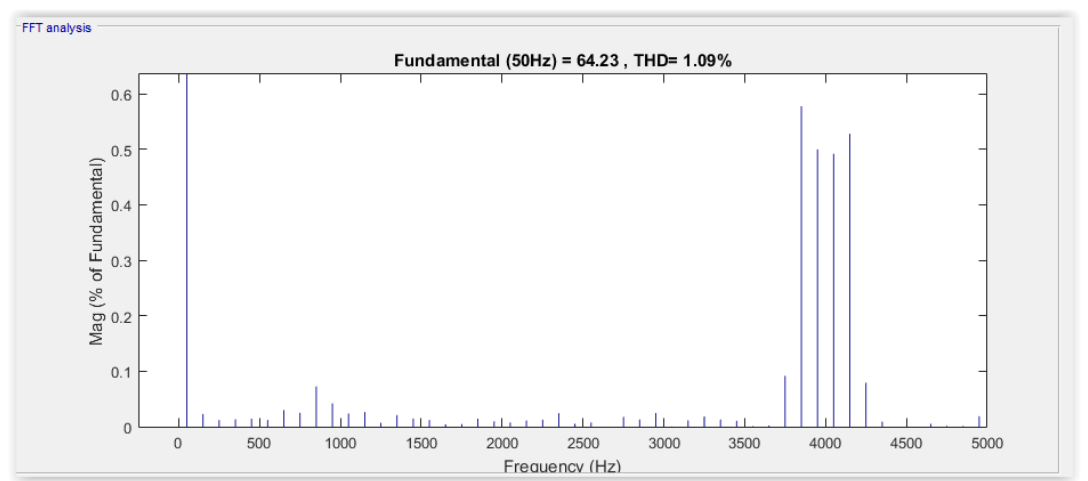

(b)

Fig 7. FFT analyses of half-bridge(a) and full-bridge(b) inverter controlling by natural-sampling PWM 


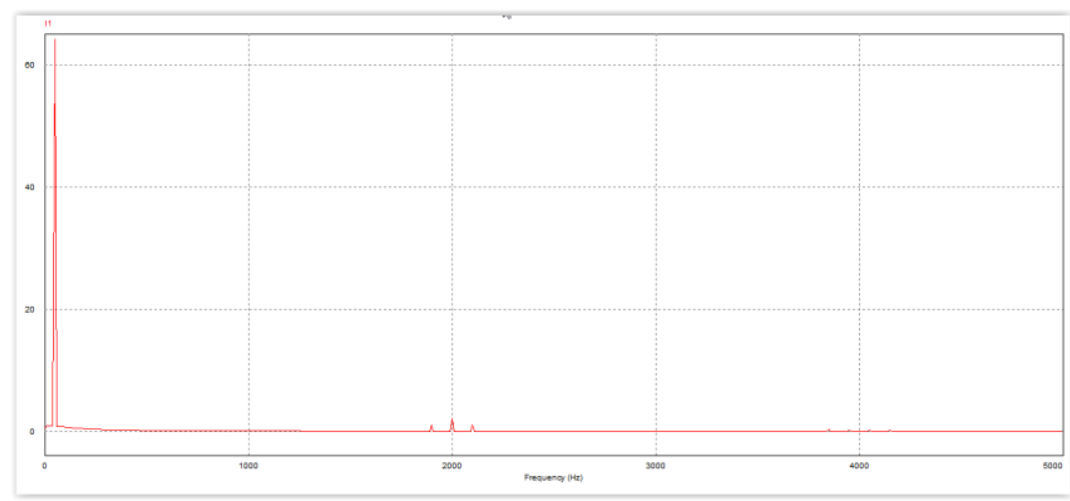

(a)

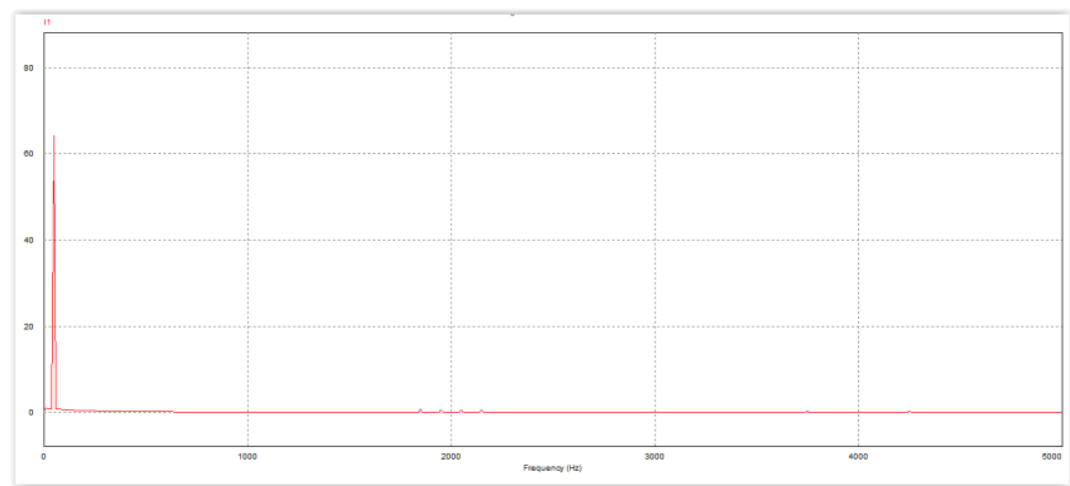

(b)

Fig 8. FFT analyses of 2-level(a) and 3-level(b) SPWM Inverters

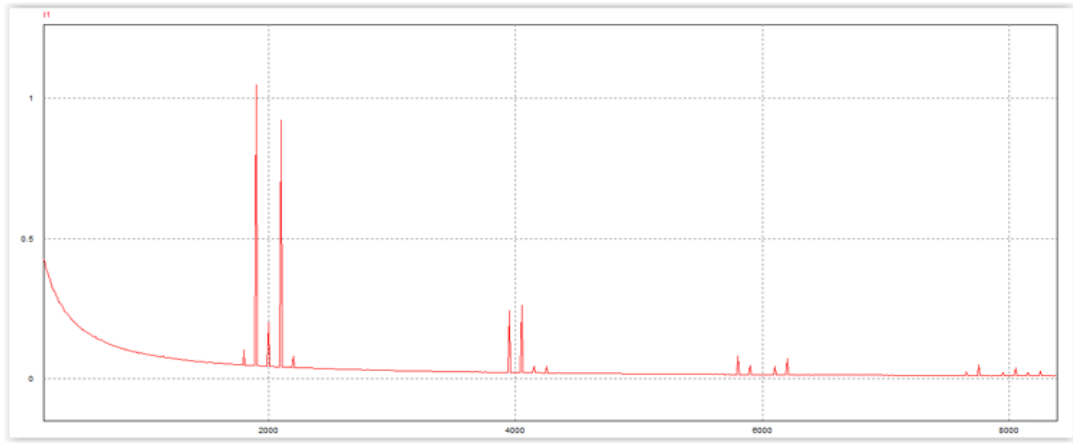

(a)

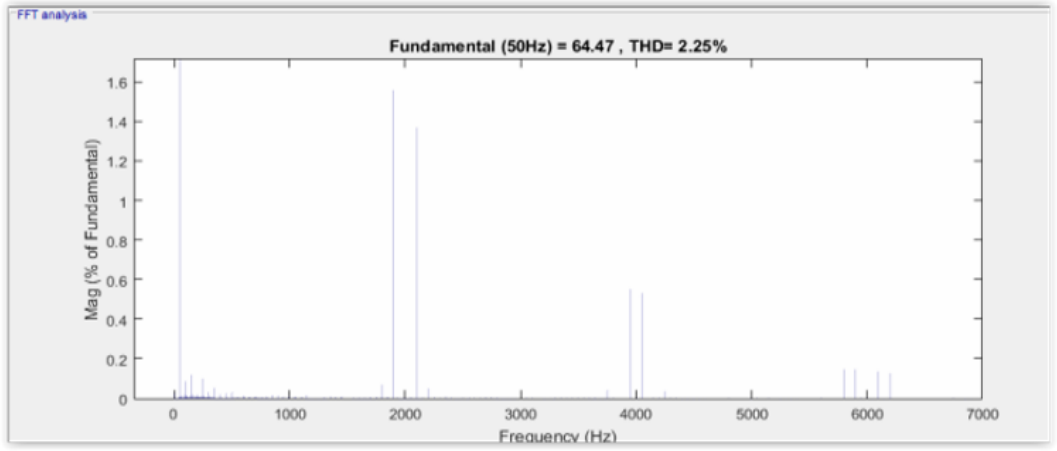

(b) 


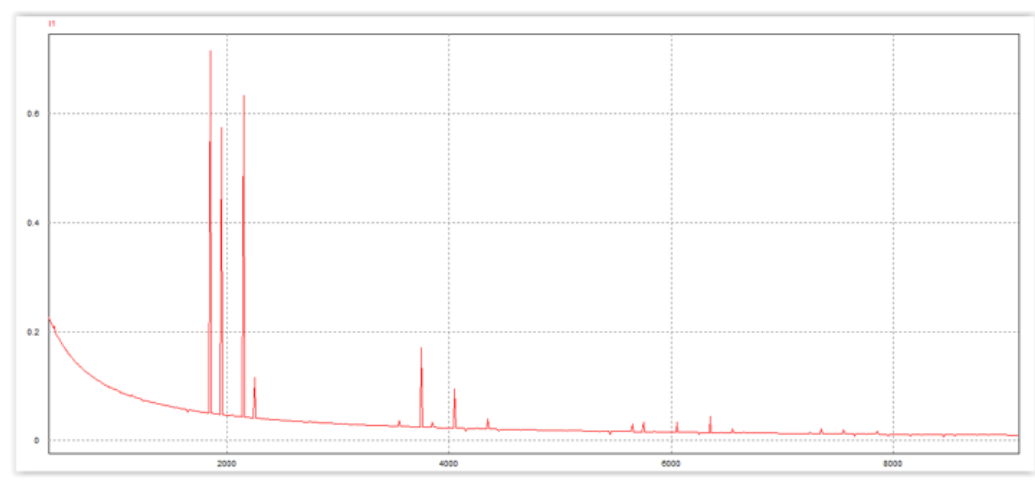

(c)

Fig 9. FFT analysis respectively uncontrolled(a) and controlled(b) full-bridge and cascaded H-bridge(c) inverters

Total harmonic distortion of single-phase topologies under 25\%, 50\%, 75\% and 100\% resistive load condition with $\mathrm{LC}$ filter which $\mathrm{C}=3.16 \mu \mathrm{F}$ is shown in Table 1 .

Table 1. THD of single-phase inverters with $\mathrm{c}=3.16 \mu \mathrm{f}$

\begin{tabular}{|c|c|c|c|c|}
\hline \multicolumn{1}{|c|}{$\begin{array}{c}\text { Inverters } \\
\text { Load }\end{array}$} & $\begin{array}{c}\text { Half-Bridge } \\
\text { In Simulink }\end{array}$ & $\begin{array}{c}\text { Full-Bridge } \\
\text { In Simulink }\end{array}$ & $\begin{array}{c}\text { 2-level SPWM } \\
\text { Full-Bridge }\end{array}$ & $\begin{array}{c}\text { 3-level SPWM } \\
\text { Full-Bridge }\end{array}$ \\
\hline $25 \%$ & $16.16 \%$ & $3.02 \%$ & $16.05 \%$ & $8.89 \%$ \\
\hline $50 \%$ & $8.87 \%$ & $2.09 \%$ & $8.94 \%$ & $4.84 \%$ \\
\hline $75 \%$ & $5.94 \%$ & $1.45 \%$ & $5.95 \%$ & $3.2 \%$ \\
\hline $100 \%$ & $4.38 \%$ & $1.09 \%$ & $4.39 \%$ & $2.32 \%$ \\
\hline
\end{tabular}

DC bias/DC injection of single phase topologies inverter is shown in Table 2.

Table 2. DC injection of single-phase inverters with $\mathrm{c}=3.16 \mu \mathrm{f}$.

\begin{tabular}{|c|c|c|c|c|}
\hline \multicolumn{1}{|c|}{ Inverters } & $\begin{array}{c}\text { Half-Bridge } \\
\text { In Simulink }\end{array}$ & $\begin{array}{c}\text { Full-Bridge } \\
\text { In Simulink }\end{array}$ & $\begin{array}{c}\text { 2-level SPWM } \\
\text { Full-Bridge }\end{array}$ & $\begin{array}{c}\text { 3-level SPWM } \\
\text { Full-Bridge }\end{array}$ \\
\hline $25 \%$ & $3.21 * 10-6 \%$ & $1.12^{*} 10^{-5} \%$ & $0.055 \%$ & $0.015 \%$ \\
\hline $50 \%$ & $3.33 * 10^{-7} \%$ & $1.3 * 10^{-6} \%$ & $0.0409 \%$ & $0.06 \%$ \\
\hline $75 \%$ & $6.2 * 10^{-10} \%$ & $6.42 * 10^{-5} \%$ & $0.172 \%$ & $0.14 \%$ \\
\hline $100 \%$ & $1.34 * 10^{-6} \%$ & $2.175 * 10^{-6} \%$ & $0.275 \%$ & $0.238 \%$ \\
\hline
\end{tabular}

As mentioned above, capacitor value increased a proper value due to decreasing THD and limit between IEEE standards. THD with increased capacitor $100 \mu \mathrm{F}$ is shown in Table 3 .

Table 3. THD of single-phase inverters with $\mathrm{c}=100 \mu \mathrm{f}$

\begin{tabular}{|c|c|c|c|c|}
\hline $\begin{array}{c}\text { Lnverters } \\
\text { Load }\end{array}$ & $\begin{array}{c}\text { Half-Bridge } \\
\text { In Simulink }\end{array}$ & $\begin{array}{c}\text { Full-Bridge } \\
\text { In Simulink }\end{array}$ & $\begin{array}{c}\text { 2-level SPWM } \\
\text { Full-Bridge }\end{array}$ & $\begin{array}{c}\text { 3-level SPWM } \\
\text { Full-Bridge }\end{array}$ \\
\hline $25 \%$ & $0.99 \%$ & $0.20 \%$ & $0.828 \%$ & $0.357 \%$ \\
\hline $50 \%$ & $0.82 \%$ & $0.12 \%$ & $0.80 \%$ & $0.349 \%$ \\
\hline $75 \%$ & $0.73 \%$ & $0.065 \%$ & $0.725 \%$ & $0.323 \%$ \\
\hline $100 \%$ & $0.36 \%$ & $0.063 \%$ & $0.72 \%$ & $0.31 \%$ \\
\hline
\end{tabular}

THD of three-phase topologies for different load condition can be shown in Table 4. DC bias or offset is shown in Table 5 All values are within acceptable limits.

Table.4. THD of 3-phase inverters

\begin{tabular}{|c|c|c|c|}
\hline $\begin{array}{c}\text { Inverters } \\
\text { Load }\end{array}$ & $\begin{array}{c}\text { 3-phase H-bridge } \\
\text { uncontrolled }\end{array}$ & $\begin{array}{c}\text { 3-phase H-bridge } \\
\text { controlled }\end{array}$ & $\begin{array}{c}\text { 3-phase 3-level } \\
\text { Cascaded H-bridge }\end{array}$ \\
\hline $25 \%$ & $3.56 \%$ & $3.67 \%$ & $3.48 \%$ \\
\hline $50 \%$ & $3 \%$ & $3.06 \%$ & $2.83 \%$ \\
\hline $75 \%$ & $2.56 \%$ & $2.57 \%$ & $2.21 \%$ \\
\hline $100 \%$ & $2.27 \%$ & $2.25 \%$ & $1.78 \%$ \\
\hline
\end{tabular}


Table.5. DC injection of 3-phase inverters

\begin{tabular}{|c|c|c|c|}
\hline Load & $\begin{array}{c}\text { 3-phase H-bridge } \\
\text { uncontrolled }\end{array}$ & $\begin{array}{c}\text { 3-phase H-bridge } \\
\text { controlled }\end{array}$ & $\begin{array}{c}\text { 3-phase 3-level } \\
\text { Cascaded H-bridge }\end{array}$ \\
\hline $25 \%$ & $0.057 \%$ & $0.058 \%$ & $0.016 \%$ \\
\hline $50 \%$ & $0.0011 \%$ & $0.006 \%$ & $0.064 \%$ \\
\hline $75 \%$ & $0.149 \%$ & $\% 0.0421$ & $0.14 \%$ \\
\hline $100 \%$ & $0.244 \%$ & $0.028 \%$ & $0.23 \%$ \\
\hline
\end{tabular}

Harmonics were observed around to $2 \mathrm{kHz}$ for half-bridge topology and around to $4 \mathrm{kHz}$ for the fullbridge topology with the help of Simulink. Harmonics were observed $2 \mathrm{kHz}$ for SPWM controlled singlephase topologies. For this reason, 40th and 80th harmonics were observed. For all 3-phase topologies, harmonics were observed around $2 \mathrm{kHz}$. In half-bridge harmonics around $2 \mathrm{kHz}$ changes between $3.54 \%$ $13 \%$ and around $4 \mathrm{kHz}$ changes $0.5 \%-1 \%$ to loading condition. For Full-bridge with PWM generator blocks, harmonics around $2 \mathrm{kHz}$ is lower than half-bridge which change between $0.5 \%-1 \%$ but around 4 $\mathrm{kHz}$ are changed between $0.6-1 \%$ and higher than half-bridge topology. For 2-level SPWM inverter harmonics around $2 \mathrm{kHz}$ changes between $3.37-14.28 \%$ also around $4 \mathrm{kHz}$ changes $0.5-1 \%$ accordingly load conditions. For 3-level SPWM harmonics are observed around $2 \mathrm{kHz}$ changes $1.25-3.76 \%$ and also around $4 \mathrm{kHz}$ changes between $0.1-0.8 \%$ according to loading condition. Harmonics are observed in multiples of $2000 \mathrm{~Hz}, 2 \mathrm{kHz}$ and $4 \mathrm{kHz}$ it can be explained with carrier-based PWM switching frequency is $2 \mathrm{kHz}$. Most of power quality standards regulate harmonics up to $35^{\text {th }}$ but in all topology in this paper $40^{\text {th }}$ an $80^{\text {th }}$ harmonics are observed. It is known that IEEE is working on this situation and standard will develop such as IEEE1547.2003.

\section{Conclusion}

Electricity demand and generating of electrical has been increasing day by day. The renewable energy system is very popular for satisfying this demand. Integrating every renewable resource into the interconnected power system, power quality is getting more complicated and power quality analysis of RES has become important. For these reasons; in this paper, 4 single-phase topologies and 3 three-phase inverter topologies which are used RESs were designed, simulated, analysed and compared in terms of THD, DC injection and individual harmonics.

According to the simulation results which mentioned above, results follows:

- For all topology max THD is observed at minimum load, min THD is observed at full-load.

- Power selection important power quality.

- As single phase designed in Simulink topologies, full bridge topology has more advantageous than half-bridge topology but the half-bridge topology is simpler than full-bridge topology.

- As single phase designed in PSIM, 3-level topology is more advantageous than 2-level topology. It can be said that if the level of PWM increased THD of an inverter decreases but control topology is the inverter will be more complicated.

- For all single phase topology, if capacitor value is increased up to the proper value, THD is decreased. Filter selection of inverter is very important.

- As three-phase topologies, min THD is observed 3-level cascaded H-bridge topology as expected.

- Level of inverter and THD is inversely related each other for single and three- phase topologies.

- THD of controlled topology is a little bit higher than uncontrolled topology due to oscillation of controller. It can be said that, controlling effects is very low and all results are consistent.

- DC injection for all topologies is acceptable and very low within certain limits.

- High order harmonics are observed in multiples of PWM switching frequency. These high order harmonics must be limited and the limits should be rearranged in the related standards accordingly.

- All power quality results are between IEEE 1547.2003 standards [14].

- As the same phase power, three-phase topologies are more advantageous than single phase topologies with same LC filter specification but inverter power of three-phase is more than single-phase.

- 3-phase topologies are more complex than single-phase topologies but less produces harmonics. 


\section{References}

[1] Bockpris O, Veziroğlu N, Smith D, Solar Energy, 1st ed, 1993, p.81.

[2] IEA, "Key world energy [Online]. http://www.iea.org/publications/freepublications/publication/keyworld 2015.pdf [Accessed: 28-Jul-2016].

[3] IEA, "How much carbon dioxide is produced when different fuels are burned?", [Online]. Available: https://www.eia.gov/tools/faqs/faq.php?id=73\&t=1, [Accessed :04-March-2017].

[4] Chapman D, Power Quality Application Guide: Harmonics Causes and Effects, Copper Development Association, March 2001.

[5] IEEE, The Authoritative Dictionary of IEEE Standards Terms, Seventh Edition, IEEE Press, 2000, page 588.

[6] Meulen AV, Maurin J, Current source inverter vs. Voltage source inverter topology, EATON Whitepaper WP20001, June 2014.

[7] Kazmierkowski MP, Malesani L, "Current control techniques for three-phase voltage-source PWM converters: a survey," in IEEE Transactions on Industrial Electronics, vol. 45, no. 5,1998:691-703,

[8] Rashid MH, Power Electronics Circuits, Devices, and Applications, 3rd ed,p.45.

[9] Kim J, Choi J, Hong H, Output LC filter design of voltage source inverter considering the performance of controller, PowerCon 2000. 2000 International Conference on Power System Technology. Proceedings (Cat. No.00EX409), Perth, WA, 2000:1659-1664 .

[10] Gole, AM. Course notes in 24.437 "Power Electronics, PWM Techniques for Harmonic Reduction in VSC", University of Manitoba, 2000.

[11] Saçli M, Ayan O, Silsüpür M, Türkay BE, Investigation of power quality analysis of three-phase inverter topologies for renewable energy systems, 2017 10th International Conference on Electrical and Electronics Engineering (ELECO), Bursa, 2017:1445-1449.

[12] Patel D, Saravanakumar R, Ray KK, Ramesh R, Design and Implementation of three Level CHB inverter with phase shifted SPWM using TMS320F24PQ, IICPE 2010, India International Conference on Power Electronics, January 28-30, 2011.

[13] Rodríguez J, Lai JS, Peng FZ, Multilevel Inverters: A Survey of Topologies, Controls, and Applications, IEEE Transactions on Industrial Electronics, 2002; 49(4):724-738.

[14] IEEE 1547 IEEE Standard for Interconnecting Distributed Resources with Electric Power Systems, IEEE Std 15472003(2009). 